\title{
THE TRUE LENDER DOCTRINE: FUNCTION OVER FORM AS A REASONABLE CONSTRAINT ON THE EXPORTATION OF INTEREST RATES
}

\author{
JOHN HANNON $\dagger$
}

\begin{abstract}
The exportation doctrine permits national and state banks to export interest rates that are legal in one state where they operate to any other state, thereby shielding the banks from liability resulting from state usury claims. The doctrine has expanded over the last forty years to permit state and national banks to preempt a variety of state consumerfinancial-protection laws. The doctrine's high-water mark is the emergence of the "rent-a-charter" arrangement, a scheme in which a nonbank lender uses a bank as a mere conduit to originate loans that are not subject to state usury laws. This Note argues that, at minimum, nonbank entities should not be allowed the benefit of the doctrine by temporarily occupying banks for the sole purpose of originating loans that are immune from state financial consumer protection laws.

A series of courts have recently begun applying a more exacting standard to these arrangements. Under the "true lender" doctrine, courts disregard the form of the lending configuration in favor of a searching examination of its substance, considering a variety of factors designed to determine which entity is the actual, rather than nominal, lender. This Note argues that the true lender doctrine's singular focus on substance over form, combined with judicial agility to examine each factual constellation and detect any obfuscating formalities implemented by rent-a-charter parties, is presently the most effective way to sensibly limit the reach of the exportation doctrine. And, to the degree that banks assume more substantive duties in the lending process and retain some measure of risk in seeking to comply with the
\end{abstract}

Copyright @ 2018 John Hannon.

$\dagger$ Duke University School of Law, J.D. expected 2018; University of Utah, B.S. 2014. Thanks to Professor Rebecca Rich and participants in the Scholarly Writing Workshop for very helpful feedback on early versions of this Note, and to the Duke Law Journal Volume 67 Executive Board for their immense efforts in refining this piece. Thanks also to my spouse, Ashtyn Hannon, for support and encouragement throughout. 
doctrine, the results are broadly consistent with regulatory approaches that have been deployed in the wake of the financial crisis.

\section{INTRODUCTION}

The exportation doctrine permits national and state banks to export interest rates that are legal in one state where they operategenerally a state with very permissive or nonexistent usury laws - to any other state, thereby shielding the banks from liability resulting from state usury claims. ${ }^{1}$ The doctrine began nearly forty years ago, and originally applied only to the nation's "most favored lenders": nationally chartered banks. ${ }^{2}$ This once-limited ability of national banks to evade state usury limits has devolved into a regime in which even nonchartered, uninsured institutions enjoy the ability to preempt a host of financial-consumer-protection laws and charge limitless interest rates $^{3}$ across the country. ${ }^{4}$

Commentators have lamented this expansive trajectory, pointing out that the original rationale for the exportation doctrine-fostering the development and maintenance of a national banking system - has long since been exceeded. ${ }^{5}$ It also appears to have been this unprincipled extension of the privilege that motivated the Second Circuit to impose an ill-considered limitation on the exportation doctrine. ${ }^{6}$ In May of 2015, the court held in Madden v. Midland Funding, $L L C^{7}$ that a third-party nonbank debt collector that had purchased charged-off ${ }^{8}$ consumer credit card debts from a nationally

1. For the statutes, judicial decisions, and regulatory interpretations that have created and shaped the exportation doctrine, see infra Part I.

2. For the origins and development of the "most favored lender" doctrine, see infra Part I.

3. Some states do not impose any interest-rate caps on loans. See, e.g., UTAH CODE ANN. § 15-1-1(1) (West 2017) ("The parties to a lawful contract may agree upon any rate of interest....").

4. See generally Elizabeth R. Schiltz, The Amazing, Elastic, Ever-Expanding Exportation Doctrine and Its Effect on Predatory Lending Regulation, 88 MINN. L. REV. 518 (2004) (chronicling the expansion of the exportation doctrine and discussing its implications).

5. See, e.g., id. at 621-22 (arguing that the expansion of the exportation doctrine to encompass the issuing of tax refund anticipation loans and payday loans by nonbanks "is not justifiable under the principles of banking law from which [the doctrine] originally derived" (emphasis in original)).

6. For an examination of the Second Circuit's motivation in the Madden decision, see infra Part II.

7. Madden v. Midland Funding, LLC, 786 F.3d 246 (2d Cir. 2015), cert. denied, 136 S. Ct. 2505 (2016).

8. "A charge-off ... is debt that is deemed unlikely to be collected by the creditor because the borrower has become substantially delinquent after a period of time." Charge-Off, 
chartered bank did not also acquire the originating bank's ability to preempt state usury laws with respect to the purchased loans. ${ }^{9}$ Prior to the decision, it was generally assumed - and two circuits had broadly indicated - that the exportation doctrine, like other contractual rights, passed with the loans to any subsequent assignee. ${ }^{10}$

The Second Circuit's ruling has upset the long-settled expectations of investors who had confidently purchased an array of securities comprised of instruments whose value was suddenly and unexpectedly compromised. ${ }^{11}$ More broadly, Madden injected an element of uncertainty into the secondary loan market, functionally imposing - at minimum-new information costs on a process otherwise characterized by unparalleled efficiency and liquidity. ${ }^{12}$

The decision prompted a range of critiques, principally from groups concerned with the decision's impact on the secondary loan market. ${ }^{13}$ Marketplace lenders and associated service industries were similarly disquieted. ${ }^{14}$ And, in a joint amicus brief, the Solicitor

INVESTOPEDIA, http://www.investopedia.com/terms/c/chargeoff.asp [http://perma.cc/J84NGQBE].

9. Madden, 786 F.3d at 250.

10. See Krispin v. May Dep’t Stores Co., 218 F.3d 919, 924 (8th Cir. 2000) (explaining "that it makes sense to look to the originating entity" to determine whether a loan preempts state usury claims); FDIC v. Lattimore Land Corp., 656 F.2d 139, 148-49 (5th. Cir. 1981) ("The non-usurious character of a note should not change when the note changes hands.").

11. For a discussion of the Madden decision's impact, see infra Part II.

12. See Michael Marvin, Note, Interest Exportation and Preemption: Madden's Impact on National Banks, the Secondary Credit Market, and P2P Lending, 116 COLUM. L. REV. 1807, 1838 (2016) ("The process of securitization may bundle borrowers of different risk profiles together, and therefore even extending credit to the least risky borrowers will entail higher transaction costs post-Madden when banks try to sell off that debt in a securitization."). For a discussion of recent legislative efforts to remedy Madden's impact, see infra note 87.

13. See, e.g., Kevin Wack, Debt-Sale Ruling Spooks Banks, Marketplace Lenders, AM. BANKER (July 24, 2015, 2:26 PM), http://www.americanbanker.com/news/marketplacelending/debt-sale-ruling-spooks-banks-marketplace-lenders-1075654-1.html [http://perma.cc/ 94XZ-D25W] (explaining that the ruling induced "a wave of anxiety at law firms, rating agencies and financial industry trade groups").

14. "Marketplace lenders are nonbank lenders that rely heavily on online marketing and underwriting platforms." OCC NAT'L RISK COMM., SEMIANNUAL RisK PERSPECTIVE (2016), https://www.occ.gov/publications/publications-by-type/other-publications-reports/semiannualrisk-perspective/semiannual-risk-perspective-spring-2016.pdf [http://perma.cc/DQ46-L9GL]. Although this group of lenders has been relying on relationships with chartered banks in order to obtain the benefits of preemption, they do not generally fit the mold of an entity seeking to enjoy the privileges accorded to banks while evading the responsibilities and constraints traditionally imposed on banks. Moreover, the Office of the Comptroller of the Currency (OCC) has recently begun the process of granting limited-purpose charters to such lenders, thereby obviating their use of partnerships with chartered institutions. See generally OCC, EXPLORING SPECIAL Purpose NATIONAL BANK Charters FOR Fintech COMPANiES (2016), 
General and the Office of the Comptroller of the Currency (OCC) unequivocally deemed the Second Circuit's analysis incorrect. ${ }^{15}$ Notwithstanding widespread discontent from the financial industry and its manifestation in the form of amici, ${ }^{16}$ the Supreme Court declined to hear the case in June of $2016 .{ }^{17}$

The Madden court, this Note argues, was motivated by a prudent desire to diminish the scope of the exportation doctrine. Notwithstanding the court's reasonable goal, the inhibitory impact that the court's blunt approach has exacted on the secondary loan market is difficult to accept, even in exchange for any progress made in limiting the reach of the doctrine. However, in a line of cases involving payday lending, a judicial trend has emerged that is more capable of achieving the Second Circuit's goal while avoiding the inefficiencies its ruling has generated: the "true lender" test.

The true lender test arose in the context of perhaps the most egregious extension of the ability to preempt state usury laws, wherein payday lenders and other nonbank entities have periodically obtained the benefits of the exportation doctrine by utilizing an arrangement commonly referred to as "rent-a-charter." ${ }^{18}$ In this model, a nonbank entity solicits borrowers, makes all the credit decisions, and directs a partner bank to originate its loans-only to purchase them from the

https://www.occ.treas.gov/topics/responsible-innovation/comments/special-purpose-nationalbank-charters-for-fintech.pdf [http://perma.cc/57BH-7F6F] (exploring whether the OCC should issue special-purpose bank charters to FinTech companies). Marketplace lenders responded enthusiastically about assuming increased responsibility and oversight in exchange for gaining access to the rights of traditional banks. See, e.g., Letter from Richard H. Neiman, Lending Club, to Thomas J. Curry, OCC, at 2 (Jan. 17, 2017), https://www.occ.gov/topics/responsibleinnovation/comments/comment-lending-club.pdf [http://perma.cc/6EDS-4WY9] ("Obtaining a national bank charter brings responsibilities alongside its privileges, and we fully support the OCC's efforts to ensure that applicants for the special purpose charter satisfy standards that protect the banking system and ensure consumers and businesses are served in a safe, fair, and responsible manner."). Because the implications of the judicial developments discussed here on the continued viability of marketplace lending are very likely to become moot in light of the OCC's fast-moving process toward the establishment of a limited national charter for such firms, this Note will not evaluate its proposals by reference to marketplace lenders.

15. Brief for the United States as Amicus Curiae at 6, Midland Funding, LLC v. Madden, 136 S. Ct. 2505 (2016) (No. 15-610). Despite its criticism of the Second Circuit's decision, the amicus brief advocated for a denial of the petition for certiorari on grounds that no genuine circuit split existed. $I d$.

16. See, e.g., Brief of the Structured Fin. Indus. Grp., Inc. \& the Sec. Indus. \& Fin. Mkts. Ass'n as Amici Curiae in Support of Petitioners, Madden, 136 S. Ct. 2505 (No. 15-610).

17. Madden, 136 S. Ct. 2505 (mem.).

18. See, e.g., West Virginia v. CashCall, Inc., 605 F. Supp. 2d 781, 783 (S.D. W. Va. 2009) (describing a payday lender's bank partnership as a "'rent-a-bank' or 'rent-a-charter' scheme designed to avoid West Virginia usury laws"). 
bank within days. This use of a chartered bank as a conduit to originate loans thereby confers on the loans the full preemptive shield of the exportation doctrine. However, a series of courts have recently begun applying a more exacting level of scrutiny to these arrangements. ${ }^{19}$ Courts applying the true lender test disregard the form of the lending configuration in favor of a searching examination of its substance, considering a variety of factors designed to determine which entity is the actual lender. ${ }^{20}$ Only after making that determination will the courts decide whether the actual lender is entitled to the broad protections granted to chartered insured ${ }^{21}$ depository institutions. In contrast to the inflexible and overbroad approach of the Madden court, the true lender doctrine looks past the superficial form of rent-acharter arrangements in order to ascertain whether the bank that is entitled to the preemption of state laws is the real lender receiving such protection. $^{22}$

This Note argues that the burgeoning true lender doctrine represents a judicial mechanism capable of imposing a sensible limit on the heretofore endless scope of the exportation doctrine, while avoiding the uncertain market conditions sown by Madden's approach. This Note further argues that the impact of the true lender doctrine on rent-a-charter arrangements is consistent with the regulatory

19. See CFPB v. CashCall, Inc., No. CV 15-7522-JFW (RAOx), 2016 WL 4820635, at *6 (C.D. Cal. Aug. 31, 2016) (applying a totality-of-the-circumstances test to determine that the nonbank entity, not the originating tribal lender, was the true lender); Pennsylvania v. Think Fin., Inc., No. 14-cv-7139, 2016 WL 183289, at *18 (E.D. Pa. Jan. 14, 2016) (denying a motion to dismiss in a usury action because plaintiffs had alleged facts sufficient to support an inference that the nonbank entity was the true lender and did not enjoy the privilege of the exportation doctrine); CashCall, Inc. v. Morrisey, No. 12-1274, 2014 WL 2404300, at*15 (W. Va. May 30, 2014), cert. denied, 135 S. Ct. 2050 (2015) (affirming the trial court's conclusion that the nonbank lender was the de facto lender and was therefore not entitled to preemption of West Virginia's usury laws).

20. While the factors being considered are largely similar between cases, courts have been generally imprecise in labeling the fledgling doctrine, resulting in several denominations in addition to true lender, such as the de facto lender test and the predominant interest test. See $C F P B, 2016 \mathrm{WL} 4820635$, at *6 (alternatingly referring to the de facto lender, the predominant economic interest, and the true lender tests); Morrisey, 2014 WL 2404300, at *14 (referring to both the true lender and the predominant interest test).

21. Insured Depository Institutions are member banks of the Federal Deposit Insurance Corporation (FDIC). Both state and nationally chartered banks may, and functionally must, join the FDIC. See Schiltz, supra note 4, at 542 n.103 ("[A]s a practical matter, federal deposit insurance is regarded as a competitive necessity.").

22. For a discussion of the cases that have developed the substance-over-form approach of the true lender doctrine, see infra Part III. 
approaches employed by the Dodd-Frank Act (Dodd-Frank) ${ }^{23}$ and might complement Dodd Frank's structural safeguards, which are designed to promote systemic safety and soundness in an increasingly interconnected financial landscape.

Part I traces the origin and progression of the exportation doctrine, explains how the doctrine is in need of a limiting principle, and details the ways in which expansive determinations of preemption of state regulation is thought to have contributed to the financial crisis. Part II reviews Madden's holding, considers the Second Circuit's likely motivation for its ruling, and details the ramifications of the court's overly broad principle in areas that may not have been anticipated. Part III describes the true lender doctrine and advocates for its enshrinement as a judicial doctrine capable of imposing and policing a line that precludes undeserving lenders from enjoying the exportation doctrine's protection without impeding unintended markets or upsetting long-settled expectations. Part III also argues that the true lender doctrine is broadly consistent with, and may help to supplement, the regulatory approaches employed by Dodd-Frank in the areas of prudential "safety and soundness" and consumer protection.

\section{THE EXPORTATION DOCTRINE AND PREEMPTION OF STATE CONSUMER PROTECTION LAWS}

The exportation doctrine grew out of a statutory scheme, and associated Supreme Court case law, that was primarily intended to protect a then-nascent national banking system from protectionist attack by the states. But over the last forty years, the doctrine has expanded in ways that have no basis in its original rationale. Notably, the exportation doctrine has been extended to allow undeserving nonbank lenders to originate loans through banks in order to evade interest-rate caps. This and related expansions have protected an array of actors from state interest-rate limitations and other consumerprotection laws that contributed, in part, to the financial crisis. Recognizing this relationship, Congress and the Supreme Court have recently acted to halt or reverse these expansive preemption trends in the area of financial-services regulation. This Part details the historical trajectory of the exportation doctrine, from its creation and subsequent expansion through the recent laws and court cases that have sought to

23. Dodd-Frank Wall Street Reform and Consumer Protection Act, Pub. L. No. 111-203, 124 Stat. 1376 (2010) (to be codified in scattered sections of the U.S. Code). 
return to the states the ability to enact and enforce consumer-financialprotection laws.

\section{A. National Banks as National Favorites}

Until the 1860s, the banking system in the United States was decentralized. ${ }^{24}$ Recognizing the shortcomings of a fragmented system - namely the inability to fund its operations - Congress set out to establish a well-functioning national banking system with a series of enactments in the mid-1860s collectively referred to as the National Bank Act (NBA). ${ }^{25}$ In addition to the creation of a national currency, one of the chief goals of the NBA was to force the conversion of statechartered banks into national charters, ${ }^{26}$ in this aim, the NBA imposed an onerous 10 percent tax on all bank notes issued by state-chartered banks. $^{27}$

Noting the clarity of purpose underlying the legislation, the Supreme Court has repeatedly interpreted ambiguities in the NBA by opting for readings that are consistent with a national vision of banking. ${ }^{28}$ And, especially when confronted with state legislation that tended to inhibit the growth of a vibrant national banking system, the Court has ruled in ways that ensured competitive equality between state and national banks or even conferred a competitive advantage on national banks. ${ }^{29}$ For example, in Tiffany $v$. National Bank of

24. See Michael S. BARR, Howell E. JACKSON \& MARgaret E. TAHYAR, FinANCIAL REgUlation: LAW \& POLICY 35-37 (2016) (detailing earlier, short-lived attempts to create a national banking system, followed by an era of decentralized "free banking").

25. See An Act to Provide a National Currency, Secured by a Pledge of United States Stocks, and to Provide for the Circulation and Redemption Thereof, ch. 58, 12 Stat. 665 (1863), repealed and reenacted with amendments by An Act to Provide a National Currency, Secured by a Pledge of United States Bonds, and to Provide for the Circulation and Redemption Thereof, ch. 106, 13 Stat. 99 (1864). See generally S. Res. 298, 66th Cong. (1920) (compiling the statutes which constitute "The National Bank Act and Acts Amendatory Thereof and Supplementary Thereto").

26. BARR ET AL., supra note 24 , at 38-39.

27. Id.

28. See, e.g., Marquette Nat'l Bank of Minneapolis v. First of Omaha Serv. Corp., 439 U.S. 299, 314-15 (1978) ("Close examination of the National Bank Act of 1864, its legislative history, and its historical context makes clear that... Congress intended to facilitate ... a "national banking system."”); Easton v. Iowa, 188 U.S. 220, 229 (1903) (explaining that by enacting the NBA, Congress sought to create a banking "system extending throughout the country, and independent, so far as powers conferred are concerned, of state legislation which, if permitted to be applicable, might impose limitations and restrictions as various and as numerous as the States").

29. See, e.g., Farmers' \& Mechs.' Nat'l Bank v. Dearing, 91 U.S. 29, 34 (1875) (finding that a state remedy for usury against national banks was preempted by the NBA, and explaining that 
Missouri, ${ }^{30}$ the Court was confronted with a Missouri statute that was intended to make banking unprofitable in the state by restricting the interest rates banks could charge while permitting all other lenders to collect interest at a higher rate. ${ }^{31}$ The Court identified congressional intent in the NBA to conclude that "National banks have been National favorites" in the eyes of the federal government, ${ }^{32}$ and as such should be permitted to charge the highest rate of interest enjoyed by any lender under state law. ${ }^{33}$ Tiffany would serve as the foundation for a hundred years of Supreme Court jurisprudence, known as the "[m]ost [f]avored [1]ender [d]octrine," in which the Court sought to implement the NBA's aim of a strong national banking system by overriding state laws that impeded this goal. ${ }^{34}$

In a continuation of this trend, the Supreme Court in Marquette National Bank of Minneapolis v. First of Omaha ${ }^{35}$ held that the NBA provision codified at 12 U.S.C. $\S 85$, which permits national banks to charge "interest at the rate allowed by the laws of the State ... where

"the States can exercise no control over [national banks], nor in any wise affect their operation, except in so far as Congress may see proper to permit").

30. Tiffany v. Nat'l Bank of Mo., 85 U.S. (18 Wall.) 409 (1873).

31. Id.

32. Id. at 413

33. Id. at 412-13. The Court has regularly noted that the establishment of a national banking system is premised on the perceived utility of such a system to the federal government. See Easton, 188 U.S. at 230 (tracing the origins of this relationship by pointing out that " $\mathrm{t}$ ] he whole opinion of the court, in McCulloch v. Maryland, is founded on, and sustained by, the idea that the bank is an instrument which is 'necessary and proper for carrying into effect the powers vested in the government of the United States."'); Davis v. Elmira Sav. Bank, 161 U.S. 275, 283 (1896) ("National banks are instrumentalities of the Federal government . . .."); Farmers' \& Mechs.' Nat'l Bank, 91 U.S. at 33 ("The national banks organized under the act are instruments designed to be used to aid the government in the administration of an important branch of the public service."). Historically, as exemplified by the temporal relationship between the Civil War and the NBA, the importance of banks to the federal government related to the use of banks to raise funds for war. See BARR ET AL., supra note 24, at 32, 34, 37 (noting that each major foray into the creation of a national banking system was related to the necessity of funding wars). In modernity, in addition to raising funds for the federal government, banks assist in the implementation of federal monetary policy. See Monetary Policy Basics, FED. REs. EduC., https://www.federalreserveeducation.org/about-the-fed/structure-and-functions/monetary-policy [https://perma.cc/GJ4D-YGSL] ("The term 'monetary policy' refers to what the Federal Reserve, the nation's central bank, does to influence the amount of money and credit in the U.S. economy. What happens to money and credit affects interest rates ... and the performance of the U.S. economy.").

34. See Schiltz, supra note 4, at 545 ("[Section] 85 consistently has been interpreted to permit national banks to make loans at the highest rates permitted any type of lender under the laws of the state in which the bank is located.").

35. Marquette Nat'l Bank of Minneapolis v. First of Omaha Serv. Corp., 439 U.S. 299 (1978). 
the bank is located," 36 allowed national banks to charge the interest rates permissible in the state in which they are located ${ }^{37}$ to customers in any other state in the country. ${ }^{38}$ The Court examined the legislative history of the NBA and the Court's own interpretations to conclude that the purpose of $\S 85$ was to facilitate a national banking system, ${ }^{39}$ and thus, any concerns about competitive equality between state and national banks ${ }^{40}$ or about the ability of states to enact usury laws were immaterial. ${ }^{41}$ With the Marquette decision, the Court created a regime-one that would come to be known as the exportation doctrine-in which a bank could be formally "located" in one jurisdiction solely for purposes of interest-rate exportation. ${ }^{42}$

\section{B. Extension to State-Chartered Banks and the Enlarged Meaning of "Interest"}

In the wake of Marquette, several states commenced a race to the bottom, either reducing or removing altogether interest-rate ceilings on consumer loans in an attempt to lure national banks. ${ }^{43}$ Faced with what turned out to be an incredible competitive disadvantage, state banks lobbied Congress to level the playing field. ${ }^{44}$ Congress responded with the Depository Institutions Deregulation and Monetary Control Act (DIDMCA), ${ }^{45}$ which borrowed statutory language from $\S 85$ to extend the privilege of interest-rate exportation

36. 12 U.S.C. $\S 85$ (2018).

37. At the time of Marquette, interstate branching was prohibited, so banks were "located" in only one jurisdiction. See Marquette Nat'l Bank of Minneapolis, 439 U.S. at 309. Accordingly, the determination of the location of a bank for purposes of interest-rate exportation was simple. The national bank in Marquette was lending via mail across state lines. $I d$. at 310.

38. Id. at 313

39. Id. at $314-15$.

40. Id. at 314 ("Whatever policy of 'competitive equality' has been discerned in other sections of the National Bank Act,... [ [ 85 and its predecessors] have been interpreted for over a century to give 'advantages to National banks over their State competitors." (quoting Tiffany v. Nat'l Bank of Mo., 85 U.S. (18 Wall.) 409, 413 (1873))).

41. Id. at 318 (rejecting the importance of the argument "that the 'exportation' of interest rates ... will significantly impair the ability of States to enact effective usury laws" because such a limitation "has always been implicit in the structure of the National Bank Act").

42. See Schiltz, supra note 4, at 543 ("Under the Exportation Doctrine... depository institutions are given the power to select one particular state's consumer credit regulation and give it preemptive effect over all other state consumer credit laws.").

43. BARR ET AL., supra note 24, at 126-27.

44. Id. at 127 .

45. Depository Institutions Deregulation and Monetary Control Act of 1980, Pub. L. No. 96-221, 94 Stat. 132 (codified as amended at 12 U.S.C.). 
to state banks. ${ }^{46}$ In Greenwood Trust Co. v. Massachusetts, ${ }^{47}$ the First Circuit confirmed that this state-chartered bank analogue of the NBA permits state banks to export interest rates in the same manner as national banks post-Marquette. ${ }^{48}$ The DIDMCA and the cases interpreting it represent the first of several transgressions of the ideological underpinnings of the exportation doctrine. That is, extending the ability to export interest rates to state-chartered banks is difficult to square with the NBA's original goal of preventing bias against nationally chartered banks in order to facilitate a vibrant national banking system. ${ }^{49}$

Over the next fifteen years, the OCC effected another enlargement of the exportation doctrine by expanding the meaning of "interest" as used in $\S 85$. Courts largely accepted the OCC's expansive interpretations of "interest" to encompass late fees ${ }^{50}$ and credit card overlimit fees. ${ }^{51}$ And in 1997, the OCC issued an interpretive letter setting forth a liberal test for determining what constitutes interest for purposes of the exportation doctrine, ${ }^{52}$ as well as providing an illustrative list. ${ }^{53}$

Finally, in the most severe violation of the underpinnings of the exportation doctrine, an array of nonbank lenders have acquired the ability to preempt state consumer-protection laws by entering into

46. See 12 U.S.C. $\$ 1831 d$ (a) (2018) (permitting interest to be charged by "[s]tate-chartered insured depository institutions . . . at the rate allowed by the laws of the State ... where the bank is located").

47. Greenwood Tr. Co. v. Massachusetts, 971 F.2d 818 (1st Cir. 1992).

48. See id. at 827 ("[W]e believe that several principles inherent in section 85 were transfused into section 521, the critical item for present purposes [being] the principle of exportation.").

49. See Schiltz, supra note 4, at 545 (explaining how $\S 85$, "a statutory provision aimed at preventing states from destroying the national banking system in its infancy, came to justify a legal doctrine preempting virtually all significant state consumer credit laws").

50. Smiley v. Citibank (S.D.), N.A., 517 U.S. 735, 740 (1996); Greenwood Tr. Co., 971 F.2d at 819 .

51. Watson v. First Union Nat'l Bank of S.C., 837 F. Supp. 146, 150 (D.S.C. 1993); Tikkanen v. Citibank (S.D.), N.A., 801 F. Supp. 270, 278 (D. Minn. 1992).

52. See OCC, Interpretive Letter No. 803, at 2 (Oct. 7, 1997) ("The term 'interest' as used in 12 U.S.C. $\$ 85$ includes any payment compensating a creditor or prospective creditor for an extension of, credit, making available of a line of credit, or any default or breach by a borrower of a condition upon which credit was extended . . ." (emphasis added) (quoting 12 C.F.R. $\S 74001(\mathrm{a})(1997)))$.

53. See id. ("[Interest] includes, among other things, the following fees connected with credit extension or availability: numerical periodic rates, late fees, not sufficient funds (NSF) fees, overlimit fees, annual fees, cash advance fees, and membership fees."). 
rent-a-charter arrangements with state and national banks,${ }^{54}$ in which a bank formally originates loans in accordance with a nonbank lender's credit decisions and then immediately sells the loans to the nonbank lender. ${ }^{55}$ While the previous enlargements of the exportation doctrine constituted expansions of what chartered banks could themselves do, the exploitation of the doctrine by rent-a-charter arrangements permits wholly undeserving entities to evade state usury limits without incurring any commensurate obligations and without serving any of the beneficial functions of traditional banks. ${ }^{56}$

\section{Expansive Preemption Determinations by the OCC and Reviewing Courts}

As illustrated by its liberal interpretations of the definition of "interest" for purposes of the exportation doctrine, the OCC has often enunciated expansive and favorable statutory interpretations for national banks. ${ }^{57}$ Moreover, when prompted to make determinations regarding the preemption of state banking and consumer-protection regulation, the OCC has invariably found that the state laws were preempted. For example, in 2004 the OCC promulgated regulations that declared that "state laws that obstruct, impair, or condition a national bank's ability to fully exercise its Federally authorized real estate lending powers" were preempted. ${ }^{58}$ This expansive blanket preemption provided that "a national bank may make real estate loans . . . without regard to state law limitations concerning" mortgage disclosures, interest rates, origination and servicing, and loan terms. ${ }^{59}$ And when OCC action was challenged in court, judicial deference to

54. The OCC maintains that, after several enforcement actions and associated guidance in the early 2000s, it has completely eliminated rent-a-charter arrangements between payday lenders and national banks. See Payday Lending, OCC, https://www.occ.treas.gov/topics/consumerprotection/payday-lending/index-payday-lending.html [https://perma.cc/4T7F-527K] (listing the enforcement actions "that eliminated these relationships from the national banking system").

55. See, e.g., BARR ET AL., supra note 24, at 622 (summarizing the proliferation of payday lenders entering into rent-a-charter arrangements).

56. See Schiltz, supra note 4, at 540-41 (explaining that privileges accorded chartered banks are tied to the important role they play as financial intermediaries, and that these privileges additionally come at the cost of "extensive regulation of almost every facet of [banks'] day-to-day operations").

57. See generally id. (detailing the various interpretations advanced by the OCC that expanded the range of state laws preempted by $\S 85$ ).

58. Bank Activities and Operations; Real Estate Lending and Appraisals, 69 Fed. Reg. 1904, 1911 (Jan. 13, 2004).

59. Id. at 1917. 
the OCC's interpretations under Chevron, U.S.A., Inc. v. Natural Resource Defense Council, Inc. ${ }^{60}$ was often dispositive. ${ }^{61}$

\section{Dodd-Frank's Spirit of Stronger State Regulatory Mechanisms}

The authors of Dodd-Frank concluded that the OCC's preemption determinations and the judicial affirmations thereof prevented the operation of strong state consumer-protection laws and enforcement in the years leading up the financial crisis. ${ }^{62}$ Dodd-Frank's drafters further concluded that this phenomenon contributed significantly to the subprime mortgage crisis. ${ }^{63}$ In response, DoddFrank seeks to return to the states the ability to effectively monitor and regulate financial institutions. ${ }^{64}$

In furtherance of this goal, Dodd-Frank prescribes the preemption standard that the OCC must use in deciding which state consumerfinancial laws are preempted. ${ }^{65}$ Whereas the OCC had previously found state laws preempted if applying the laws would merely "obstruct, impair, or condition" the operation of a national bank, Dodd-Frank requires a higher preemption standard. Dodd-Frank incorporates the preemption standards of a Supreme Court case, Barnett Bank of Marion County, N.A.v. Nelson, ${ }^{66}$ which preempts state laws that "prevent[] or significantly interfere[] with the exercise by the national bank of its powers." ${ }^{67}$ Dodd-Frank also requires the OCC to

60. Chevron, U.S.A., Inc. v. Nat. Res. Def. Council, Inc., 467 U.S. 837 (1984).

61. See, e.g., Smiley v. Citibank (S.D.), N.A., 517 U.S. 735, 739 (1996) (applying Chevron deference to the OCC's interpretation of "interest" as encompassing late fees); Wachovia Bank, N.A. v. Watters, 431 F.3d 556, 560 (6th Cir. 2005) (affirming the district court's Chevron analysis that concluded that the OCC's finding of preemption of a state registration and consumerprotection-investigation law was reasonable), aff'd, 550 U.S. 1 (2007); see also Schiltz, supra note 4, at 620 ("A close analysis of expansion of the substantive scope of the Exportation Doctrine illustrates the vigor of judicial deference to federal agency interpretations in the area of consumer credit regulation.").

62. See S. REP. No. 111-176, at 17 (2010) (concluding that the OCC's preemption decisions had "actively created an environment where abusive mortgage lending could flourish without State controls").

63. Id.

64. See, e.g., 12 U.S.C. $\S 25 \mathrm{~b}$ (2018) (imposing a host of requirements on the analysis of preemption of state consumer-financial laws). See generally Arthur E. Wilmarth, Jr., The DoddFrank Act's Expansion of State Authority To Protect Consumers of Financial Services, 36 J. CORP. L. 893 (2011) (examining provisions in Dodd-Frank that empower states to enact and enforce consumer-financial-protection laws).

65. See Wilmarth, supra note 64, at 927-30.

66. Barnett Bank of Marion Cty., N.A. v. Nelson, 517 U.S. 25, 33 (1996).

67. 12 U.S.C. $\S 25 \mathrm{~b}(\mathrm{~b})(1)(\mathrm{B})$ (emphasis added). 
make such preemption determinations on a case-by-case basis ${ }^{68}$ a clear rejection of the OCC's blanket preemption of state mortgage-lending regulation in 2004. ${ }^{69}$ Additionally, in an apparent assignment of blame to the OCC for its expansive interpretations about which state consumer-financial laws were preempted for national banks before the financial crisis, Dodd-Frank expressly prescribes a more searching standard of review for courts reviewing such OCC determinations. ${ }^{70}$

Post-financial crisis, the Supreme Court has also enunciated a more restrictive view of financial regulation preemption. The paradigmatic example is the Court's rejection of preemption of state regulation in Cuomo v. Clearing House Association, ${ }^{71}$ in which the Court's review of an OCC regulation concerning preemption seemed rather different than its approach to a similar regulation two years prior in Watters v. Wachovia Bank, N.A. ${ }^{72}$ In Watters-decided in 2007, before the financial crisis - the Court upheld an OCC regulation that permitted a mortgage-lending subsidiary of a national bank to enjoy the same preemption of state consumer-financial-protection laws as its

68. Id. The provision additionally requires that, in making preemption determinations on a case-by-case basis, the OCC "shall first consult with the Bureau of Consumer Financial Protection and shall take the views of the Bureau into account when making the determination." Id. $\S 25 \mathrm{~b}(\mathrm{~b})(3)(\mathrm{B})$.

69. See Bank Activities and Operations; Real Estate Lending and Appraisals, 69 Fed. Reg. 1904 (Jan. 13, 2004) (promulgating rule preempting all state mortgage laws "that obstruct, impair, or condition a national bank's ability to fully exercise its Federally authorized real estate lending powers"). In 2011 , as required by $\S 25$ b, the OCC implemented a final rule removing the "obstruct, impair, or condition" language from the regulation, and inserting the above-mentioned statutorily prescribed changes into its regulations. Office of Thrift Supervision Integration; DoddFrank Act Implementation, 76 Fed. Reg. 43549, 43551-52, 43556 (July 21, 2011) (current version codified at 12 C.F.R. $\$ 34.4$ (2018)).

70. Congress expressly revoked from the OCC the very deferential standard of review for courts reviewing agency determinations announced in Chevron, U.S.A., Inc. v. Natural Resources Defense Council, Inc., 467 U.S. 837, 843-44 (1984). See 12 U.S.C. § 25b(b)(5)(A) (directing courts reviewing the OCC's preemption determinations for state consumer-financial laws to apply a more stringent standard of review, involving an assessment of "the validity of such determinations, depending upon the thoroughness evident in the consideration of the agency, the validity of the reasoning of the agency, the consistency with other valid determinations made by the agency, and other factors which the court finds persuasive and relevant").

71. Cuomo v. Clearing House Assoc., 557 U.S. 519, 536 (2009).

72. Watters v. Wachovia Bank, N.A., 550 U.S. 1, 20-22 (2007); see Arthur E. Wilmarth, Jr., Cuomo v. Clearing House: The Supreme Court Responds to the Subprime Financial Crisis and Delivers a Major Victory for the Dual Banking System and Consumer Protection 14 (GWU Legal Studies Research Paper No. 479, 2010), https://papers.ssrn.com/sol3/papers.cfm?abstract_id $=1499216$ [https://perma.cc/3JG9-V33G] (noting the opposite rulings on highly similar facts, and reviewing the Cuomo decision to illustrate the difference between the Court's pre-financial crisis decisions affirming OCC preemption determinations and its post-financial crisis decisions restricting the OCC's preemption determinations). 
parent bank..$^{73}$ But in Cuomo-decided in 2009, as the damage caused by the subprime mortgage crisis was on full display - the Court rejected an OCC regulation which forbid state attorneys general from bringing actions to enforce state law against national banks. ${ }^{74}$ Although the four dissenting justices in Cuomo maintained that the Court's opinion in Watters should lead the Court to sustain the regulation on the same grounds ${ }^{75}$ the majority opinion attempted to narrow the precedential scope of Watters. ${ }^{76}$

\section{THE MADDEN DECISION, ITS RAMIFICATIONS, AND THE MOTIVES OF THE SECOND CIRCUIT}

The Second Circuit's opinion in Madden, which held that a nonbank third-party debt collector was not entitled to receive the protection of the exportation doctrine,${ }^{77}$ has caused uncertainty in a variety of financial-services contexts. In withholding the doctrine from the debt collector, the court-seemingly motivated by a number of sensible concerns-effectively limited the type of actors that are entitled to the doctrine's privileges. The information costs generated by the decision, however, have proved too great to accept in exchange for any success in halting the trend of expansive financial regulation preemption.

The plaintiff in Madden brought suit-as the representative of a putative class - against a debt collector, Midland Funding, LLC, who had purchased her charged-off credit card debt from Bank of America. ${ }^{78}$ Bank of America, who, as a nationally chartered bank, is uncontrovertibly entitled to the exportation doctrine, had originated and serviced the debt at issue until it became nonperforming, at which point the bank sold the debt to Midland Funding. ${ }^{79}$ The suit alleged,

73. Watters, 550 U.S. at 20-22; see Wilmarth, supra note 72, at 2 ("Watters took a broad view of the preemptive reach of the NBA ....").

74. Cuomo, 550 U.S. at 529-33.

75. See id. at 552 (Thomas, J., dissenting) ("Finally, this Court's decision in Watters... supports OCC's construction of the statute.").

76. See Wilmarth, supra note 72 , at 12 (examining each opinion to conclude that "[t]he majority opinion in Cuomo sharply limited the scope and precedential effect of the Court's previous opinion in Watters").

77. Madden v. Midland Funding, LLC, 786 F.3d 246, 247 (2d Cir. 2015), cert. denied, 136 S. Ct. 2505 (2016) (mem.).

78. Id. at 247-48. Midland actually acquired the debt from Bank of America subsidiary bank FIA Card Services, N.A., which is also nationally chartered. Id.

79. Id. at 248 . 
inter alia, that Midland's assessment of 27 percent interest on the debt was usurious under New York law. ${ }^{80}$ The district court entered judgment for Midland, finding that the debt collector was entitled to the same protection from state usury law claims as the originating bank. ${ }^{81}$ On appeal, the Second Circuit reversed after finding, in accordance with the preemption analysis announced by the Supreme Court in Barnett, ${ }^{82}$ that applying state usury laws against Midland (that is, declining to apply the exportation doctrine) would not "significantly interfere with [the national bank's] ability to exercise its powers under the [NBA]." ${ }^{\prime 3}$ The court conceded that the ruling might depress the price at which a national bank could sell its nonperforming debt to third parties, but indicated that such an effect did not rise to the level of "significant interference." 84

What the Second Circuit either failed to consider or believed unlikely to materialize was the impact of its analysis beyond the context of third-party debt collectors. Specifically, the court may not have anticipated the extension of its ruling to an enormous ${ }^{85}$ secondary loan market that benefits a variety of actors. ${ }^{86}$

The Madden ruling injected an unprecedented element of uncertainty into a market that had long relied on the fixed quality of debt obligations underlying securities. ${ }^{87}$ Though ruling on the

80. Id.; see N.Y. PENAL LAW $\S 190.40$ (McKinney 2010) (capping permissible interest rates at 25 percent).

81. Madden, 786 F.3d at 248.

82. Barnett Bank of Marion Cty., N.A. v. Nelson, 517 U.S. 25, 33 (1996). For a discussion of Congress's codification of the Barnett standard as part of a trend toward returning the ability to regulate financial institutions to the states, see supra Part I.

83. Madden, 786 F.3d at 251.

84. Id. The Second Circuit remanded the case for the district court to make a further determination on the effect of a choice-of-law provision in the loan agreements. Id. at 249. On remand, the district court found that to give effect to the choice-of-law provision and apply Delaware's more permissive interest rate limitations would violate a fundamental public policy of New York state. See Madden v. Midland Funding, LLC, 237 F. Supp. 3d 130, 151 (S.D.N.Y. 2017) ("I will thus apply New York law to Plaintiff's claims.").

85. See generally Brief of the Structured Fin. Indus. Grp., Inc., \& the Sec. Indus. \& Fin. Mkts. Ass'n as Amici Curiae in Support of Petitioners, supra note 16 (describing the size of the secondary market).

86. See BD. OF Governors of THE Fed. Reserve Sys., Report to the Congress on RISK RETENTION 8-9 (2010), http://www.federalreserve.gov/boarddocs/rptcongress/ securitization/riskretention.pdf [https://perma.cc/GG2N-MNYK] (reviewing the economic benefits to market participants flowing from securitization and speculating that these benefits "may lower the cost of credit to households and businesses").

87. See Bryan Chegwidden, Second Circuit Decision Could Disrupt Secondary Market for Bank-Originated Loans, HARV. L. SCH. F. ON CORP. Governance \& Fin. Reg. (2015), 
preemptive scope of national bank lending, commentators have noted that the same limitation might be applied by future courts to the identical provision for state-chartered banks, increasing the uncertainty faced by assignees of bank-originated loans. ${ }^{88}$

Facially, in light of the sheer size of securitization in the American economy ${ }^{89}$ a rule that ties the legality of a loan's terms to the entity that holds it seems likely to seriously impede both the efficiency and the liquidity of the system, reducing or eliminating the benefits securitization confers..$^{90}$ One of the principal benefits of securitization

https://corpgov.law.harvard.edu/2015/07/08/second-circuit-decision-could-disrupt-secondarymarket-for-bank-originated-loans [https://perma.cc/CJP2-VKWX] ("Consequently, unless reversed, Madden could significantly disrupt the secondary market for bank loans originated by national banks, as well as affect the valuation of such loans already held by non-bank investors."). Congress has recently introduced "Madden fix" bills in both chambers that would, in essence, codify the contractual principle of "valid-when-made." E.g., Protecting Consumers' Access to Credit Act of 2017, S. 1642, 115th Cong. (referred to the Committee on Banking, Housing, and Urban Affairs on July 27, 2017). For instance, the Protecting Consumers' Access to Credit Card Act of 2017 would insert the following language into both $\S 85$ of the NBA and its analogue at $\S 1831 \mathrm{~d}$ :

A loan that is valid when made as to its maximum rate of interest in accordance with this subsection shall remain valid with respect to such rate regardless of whether the loan is subsequently sold, assigned, or otherwise transferred to a third party, and may be enforced by such third party notwithstanding any State law to the contrary.

Id. Professor Adam Levitin has persuasively detailed his concerns that the bill might pave the way for increased predatory lending. Adam J. Levitin, 'Madden Fix' Bills are a Recipe for Predatory Lending, AM. BANKER (Aug. 28, 2017, 10:24 AM), https://www.americanbanker.com/opinion/ madden-fix-bills-are-a-recipe-for-predatory-lending [https://perma.cc/4H8R-YAHQ]. Levitin fears that the bills' failure to distinguish between "relatively benign transactions, like credit card securitization or even facilitating a secondary market in defaulted loans" from "schemes that have no purpose other than the evasion of state usury laws and other consumer protections" will serve to congressionally authorize these latter transactions. Id. However, as explained infra at Part III.B, even if a Madden fix law is enacted, a robust application of the true lender doctrine shouldat least with respect to rent-a-charter lenders-operate to prevent this outcome, as the test does not ever arrive at a conclusion that a loan has become usurious upon sale or assignment, but rather that it was invalid even at the point of origination because it was not genuinely "made" by a lender entitled to charge such interest rates. Stated another way, the true lender doctrine seeks to identify whether loans truly were valid-when-made, and only an affirmative answer will even trigger application of the Madden fix law.

88. See Marc P. Franson, Michael S. Himmel, Peter C. Manbeck \& Kenneth P. Marin, Federal Court Decision Creates Uncertainty for Non-Bank Loan Assignees Regarding the Scope of Federal Preemption of State Usury Laws, 132 BANKING L.J. 413, 415-16 (2015) (explaining that the decision's impact may ultimately be applied to state-chartered banks).

89. See Brief of the Structured Fin. Indus. Grp., Inc. \& the Sec. Indus. \& Fin. Mkts. Ass'n as Amici Curiae in Support of Petitioners, supra note 16, at 10 (finding nine trillion dollars in loans securitized in 2014).

90. See BARR ET AL., supra note 24, at 1140-42 (reviewing the benefits and logic of securitization). 
is the increased lending it facilitates. ${ }^{91}$ Indeed, the ability of banks to offer a variety of lending options to consumers and businesses is inextricably tied to a well-functioning secondary market. ${ }^{92}$ A skittish secondary market invariably dampens banks' willingness to extend credit. Unsure whether there will be a market for pools of loans that will otherwise remain on their balance sheets, banks lend more sparingly.

Empirically, the Madden ruling has reduced the value in the secondary market of potentially usurious loans ${ }^{93}$ Moreover, even if the loans and parties in a transaction on the secondary loan market are unaffected by Madden-by virtue of having no nexus with Second Circuit states-the decision has nevertheless imposed on them additional information costs by forcing them to ascertain whether the loans they are buying are subject to the Second Circuit's new rule. ${ }^{94}$

Several facets of the Madden opinion suggest that the court was motivated, at least in part, by a desire to withhold the benefits of the exportation doctrine from nonbank entities. While the effect of the ruling has emanated-perhaps unintentionally-beyond the market segments represented by the parties to the case, the court's analysis was far from unsophisticated. Indeed, the opinion evidences an awareness of the troublingly expansive scope of the exportation doctrine, as well as an understanding of several broad trends in financial regulation that are designed to remedy some of the problems thought to have led to the financial crisis.

For example, the court indicated its discomfort with the breadth of the exportation doctrine, expressing its unease about "an overly broad application" of the doctrine.${ }^{95}$ It further characterized the effect

91. See generally Lowell L. Bryan, Structured Securitized Credit: A Superior Technology for Lending, 1 J. APPLIED CORP. FIN. 6 (1988) (delineating the benefits of securitizations to banks, investors, and borrowers via increased availability of credit).

92. See Brief of the Structured Fin. Indus. Grp., Inc. \& the Sec. Indus. \& Fin. Mkts. Ass'n as Amici Curiae in Support of Petitioners, supra note 16, at 6 ("The ability to securitize bank loans is fundamentally important to banks, borrowers, and the economy.").

93. Colleen Honigsberg, Robert J. Jackson, Jr. \& Richard Squire, How Does Legal Enforceability Affect Consumer Lending? Evidence from a Natural Experiment, J.L. \& ECONS. (forthcoming 2018) (manuscript at 4), https://papers.ssrn.com/sol3/papers.cfm?abstract_id= 2780215\&download=yes [https://perma.cc/5LRQ-F5X2].

94. See Marvin, supra note 12 , at $1837 \&$ n.185 (collecting sources that illustrate the costs imposed on the secondary market by the imposition of new requirements of due diligence postMadden).

95. Madden v. Midland Funding, LLC, 786 F.3d 246, 251 (2d Cir. 2015), cert. denied, 136 S. Ct. 2505 (2016). 
of preempting state usury laws for debt collectors as tantamount to creating "an end-run around usury laws for non-national bank entities that are not acting on behalf of a national bank." 96

Additionally, the Second Circuit's principal reliance on Barnett's "prevents or significantly interferes" standard of preemption is a goodfaith application of Dodd-Frank's more stringent standard for finding preemption of state consumer-protection laws. As discussed in Part I, Congress codified the more restrictive standard from Barnett in DoddFrank with a clear intent to repudiate both the OCC's expansive preemption interpretations and similarly permissive judicial decisions leading up to the financial crisis. ${ }^{97}$ The Barnett standard thus intentionally imposed a variety of restraints on the OCC and reviewing courts in making preemption determinations moving forward. ${ }^{98}$

Madden's analysis of relevant case law similarly evidences a circumscribed view of the exportation doctrine, one that is consistent with an increased regulatory focus on risk retention by originating entities. ${ }^{99}$ The court's discussion of on-point cases reveals a conception of the exportation doctrine in which the doctrine is only properly extended when the loan remains relatively close to the originating bank. Specifically, presented with sister circuit precedent that appeared to weigh in favor of the opposite ruling, the court distinguished each case by reference to the role the banks continued to play in those cases, whether they retained some portion of ownership of the debt or continued to collect its interest. ${ }^{100}$ The court concluded that because Midland and the originating banks were entirely separate entities and because the originating bank had no ongoing interest in the loan, Midland was not entitled to the exportation doctrine. ${ }^{101}$

Moreover, the Second Circuit in Madden focused on the proper limits of preemption of state usury law claims to the exclusion of the contract principle known as "valid-when-made," which dictates that a

96. Id. at $251-52$.

97. Madden, 786 F.3d at 251-52.

98. Id.

99. For a discussion of risk retention as a regulatory approach to realign incentives in the origination and securitization processes, see infra Part III.C.

100. See Madden, 786 F.3d at 252 (distinguishing Krispin v. May Dept. Stores Co., 218 F.3d 919 (8th Cir. 2000), on grounds that in that case "the national bank retained ownership of the accounts"); id. at 253 (distinguishing Phipps v. FDIC, 417 F.3d 1006 (8th Cir. 2005), on grounds that in that case "the national bank was the entity that charged the interest to which the plaintiffs objected").

101. Id. at 252-53. 
loan that is not usurious when it is made cannot become usurious upon assignment. $^{102}$ The Restatement of Contracts, the Uniform Commercial Code, and centuries of case law support the principle of valid-when-made, reinforcing the intuitive notion that loan obligations are, in essence, currency whose validity cannot be disrupted by the mere substitution of obligees. ${ }^{103}$ The court's seemingly deliberate decision to focus on preemption to the exclusion of the contract analysis further strengthens the inference that its principal motivation was the imposition of a constraint on the exportation doctrine.

Finally, the Madden court's adoption of key arguments from the plaintiff-appellant's brief hints at the court's motivation to shrink the exportation doctrine. ${ }^{104}$ That brief advocated for a limited conception of federal preemption on several grounds, citing the various requirements that Dodd-Frank placed on preempting state consumerprotection laws and pointing to administrative trends toward narrowing the scope of preemption. ${ }^{105}$ In addition to setting forth the roadmap that the court would eventually use to distinguish precedent from other circuits, ${ }^{106}$ the plaintiff-appellant's brief explicated how the Second Circuit should-and in fact, exactly how it did-apply the current, more stringent standard from Dodd-Frank to find that the state usury laws were not preempted. ${ }^{107}$ That the court's opinion closely tracked a brief dedicated primarily to contracting the scope of state consumer-protection-law preemption seems to suggest that the decision was motivated by a similar purpose.

102. See Brief for the United States as Amicus Curiae, supra note 15, at 8 ("Under the longestablished 'valid-when-made' rule, if the interest-rate term in a bank's original loan agreement was nonusurious, the loan does not become usurious upon assignment, and so the assignee may lawfully charge interest at the original rate.").

103. See Nichols v. Fearson, 32 U.S. (7 Pet.) 103, 109 (1833) (delineating the "cardinal rule[] in the doctrine of usury" that "a contract, which, in its inception, is unaffected by usury, can never be invalidated by any subsequent usurious transaction"); RESTATEMENT (SECOND) OF CONTRACTS § 336(2) (AM. LAW INST. 1981) ("The right of an assignee is subject to any defense or claim of the obligor which accrues before the obligor receives notification of the assignment, but not to defenses or claims which accrue thereafter ....”); U.C.C. § 2-210(2) (AM. LAW INST. \& UNIF. LAW COMM'N 1977) ("Unless otherwise agreed all rights of either seller or buyer can be assigned ....").

104. See Brief for Plaintiff-Appellant at 12, 14-15, 21-25, 33, 39, Madden, 786 F.3d 246 (No. 14-2131-cv) (setting forth each of the arguments the Second Circuit would ultimately adopt in its opinion).

105. Id. at $39-42$.

106. Id. at 25. For a discussion of the court's distinguishing precedent, see supra note 100 and accompanying text.

107. Brief for Plaintiff-Appellant, supra note 104, at 39 


\section{THE “TRUe LENDER” DOCTRINE}

A recent string of cases, seemingly motivated in part by the same concerns as the Madden court-nondeserving institutions exploiting the exportation doctrine-have developed and implemented a regime that effectively excises those nondeserving lenders from the scope of the exportation doctrine while avoiding the overly broad effects of Madden. Instead of the imposition of a bright-line rule like that in Madden, where the loan holder's status as a nonbank at the time of adjudication was dispositive, the true lender doctrine eschews form in favor of substance, examining the economic realities of lending arrangements to determine whether the real originator of the loan is entitled to the broad protection of the exportation doctrine.

\section{A. History of the True Lender Doctrine}

The true lender doctrine traces its origins to an effort by Georgia's legislature to eliminate in-state payday lenders that were circumventing the state's usury laws by entering into rent-a-charter arrangements with out-of-state banks. ${ }^{108}$ The Georgia law codified a totality-of-the-circumstances test to determine when a "purported agent shall be considered a de facto lender" for purposes of applying state usury laws. ${ }^{109}$ The touchstone of the statute's test is that an agent will be considered the de facto lender when "the entire circumstances of the transaction show that the purported agent holds, acquires, or maintains a predominant economic interest in the revenues generated by the loan." 110

Seemingly influenced, at least in part, by the Georgia statute, the first judicial deployment of the test to reach resolution on the merits ${ }^{111}$

108. GA. CodE AnN. § 16-17-2(b)(4) (2011). See generally John D. Skees, Note, The Resurrection of Historic Usury Principles for Consumption Loans in a Federal Banking System, 55 CATH. U. L. REV. 1131 (2006) (discussing the Georgia statute and its subsequent legal challenges, and advocating for the enactment of similar laws in other states).

109. GA. CODE ANN. § 16-17-2(b)(4).

110. Id.

111. An incipient version of the doctrine was applied in a series of payday-lending cases in the early 2000s. While these cases appear to have partially inspired the recent true lender cases, the discussions in these early cases are confined to the propriety of removal to federal court of state actions after preemption is asserted as a basis for subject matter jurisdiction. See, e.g., Colorado ex rel. Salazar v. Ace Cash Express Inc., 188 F. Supp. 2d 1282, 1285 (D. Colo. 2002) (remanding to state court because the NBA cannot form the basis of "federal question removal jurisdiction in actions against entities which are not banks"). Accordingly, these courts never ruled on whether state usury claims are preempted in the face of a true lender theory. See 
appears to have been in People ex rel. Spitzer v. County Bank of Rehoboth Beach. ${ }^{112}$ In Rehoboth Beach, New York's attorney general brought an action against two nonbank payday lenders and their Delaware-chartered bank partner, alleging that all three were part of "a scheme to permit [the payday lenders] to circumvent New York's usury laws." 113 The defendants urged the New York appeals court to adopt a test to find that the chartered bank, not the nonbank entities, was the lender for purposes of determining choice of usury law. ${ }^{114}$ This test was developed by the OCC to help national banks determine where a loan is made for purposes of deciding which state's interest rate limits are to be exported. ${ }^{115}$ The exceedingly formalistic test provides that a loan is made where each of three primary lending functions occur"the decision to extend credit, the extension of credit itself, and the disbursal of the proceeds of a loan." 116 The adoption of this test would have conclusively identified the chartered bank as the lender. The court, however, rejected this test, explaining:

It strikes us that we must look to the reality of the arrangement and not the written characterization that the parties seek to give it, much like Frank Lloyd Wright's aphorism that "form follows function." Thus, an examination of the totality of the circumstances surrounding this type of business association must be used to determine who is the "true lender," with the key factor being "who had the predominant economic interest" in the transactions. ${ }^{17}$

Several years later, the West Virginia Supreme Court, citing Rehoboth Beach, embraced the true lender test. ${ }^{118}$ The West Virginia

CashCall, Inc. v. Morrisey, No. 12-1274, 2014 WL 2404300, at*14 (W. Va. May 30, 2014) (explaining that the removal cases "were not adjudicated on the merits").

112. People ex rel. Spitzer v. Cty. Bank of Rehoboth Beach, 846 N.Y.S.2d 436 (App. Div. 2007).

113. Id. at 438

114. Id.

115. See OCC, Interpretive Letter No. 822, at 2-3 (Feb. 17, 1998) (elucidating the test for where a bank is "located" for purposes of the exportation doctrine).

116. Id. at 8 (emphasis removed) (quoting 140 CONG. REC. S12,789 (daily ed. Sept. 13, 1994) (statement of Sen. Roth)).

117. Bank of Rehoboth Beach, 846 N.Y.S.2d at 438-39. The court remanded the case to the district court, $i d$. at 439 , after which the parties settled for $\$ 5.2$ million. Press Release, N.Y. State Office of the Att'y Gen., Attorney General Cuomo Announces Distribution of \$5.2 Million Settlement in "Rent-a-Bank" Payday Lending Scheme (Nov. 17, 2009), http://www.ag.ny.gov/press-release/attorney-general-cuomo-announces-distribution-52-millionsettlement-rent-bank-payday [https://perma.cc/6AZE-E2XG].

118. See CashCall, Inc. v. Morrisey, No. 12-1274, 2014 WL 2404300, at*15 (W. Va. May 30, 2014). 
Supreme Court affirmed the trial court's application of the test to conclude that the nonbank payday lender CashCall, not its statechartered bank partner that formally originated its loans, was the true or de facto lender of the loans at issue. ${ }^{119}$ The nonbank defendants, like the nonbanks in Rehoboth Beach, had urged the court to conclude that the real lender should be determined by simple reference to which entity both set the terms and conditions of the loan and extended the credit. ${ }^{120}$ The court characterized this test as an examination of "only the superficial appearance of CashCall's business model." 21 Accordingly, the court affirmed the trial court's conclusion, sufficiently supported by its "extraordinarily thorough" opinion, ${ }^{122}$ that the arrangement between CashCall and its bank partner "placed the entire monetary burden and risk of the loan program on CashCall, and not on [the bank]." 123

Because CashCall was not entitled to federal preemption of state usury law claims, the West Virginia Supreme Court affirmed the trial court's determination that the loans were usurious. ${ }^{124}$ The court further affirmed a $\$ 10$ million judgment - a figure arrived at by quadrupling the amount of interest charged to CashCall's 292 debtors in West Virginia-as well as the trial court's determination that all of CashCall's loans to West Virginians were void and "any debts still owing ... cancelled." 125

\footnotetext{
119. Id. at $* 14-15$.

120. Id. at $* 14$.

121. Id. at $* 15$.

122. Id. at $* 24$. The trial court found that:
}

CashCall had to procure the personal guarantee of its sole owner and stockholder ... to personally guarantee all of CashCall's financial obligations to the [bank], including the amounts of the loans prior to "purchase" by CashCall. Also, CashCall had to indemnify [the bank] against all losses arising out of the Agreement, including claims asserted by borrowers. CashCall was under a contractual obligation to purchase the loans originated and funded by [the bank] only if CashCall's underwriting guidelines were followed when approving the loan.

Id. at $* 7$.

123. Id. at $* 6$.

124. Id. at $* 7$.

125. Id. at $* 8$. Jurisdictions are divided on whether a usurious loan should be judicially reformed, making only the impermissible interest uncollectable, or whether a finding of usury renders the entire loan void. Compare id., with McCormick v. Indep. Life \& Annuity Co., 794 F.3d 817, 818 (7th Cir. 2015) ("Cancellation of the principal balance as a remedy for excessive interest is legally impossible in Wisconsin ....”). 
Apparently buoyed by the success against CashCall in West Virginia and another case in Maryland, ${ }^{126}$ the Consumer Financial Protection Bureau (CFPB) successfully persuaded a federal district court in California to apply the true lender test to CashCall's partnership with a tribal financial institution on the Cheyenne reservation in CFPB v. CashCall, Inc. ${ }^{127}$ In this partnership, as described by the court:

CashCall, and not [the originating bank], placed its money at risk. It is undisputed that CashCall deposited enough money into a reserve account to fund two days of loans ... and that [the originating bank] used this money to fund consumer loans. It is also undisputed [that] CashCall purchased all of [the originating bank's] loans, and in fact paid [the bank] more for each loan than the amount actually financed .... Although CashCall waited a minimum of three days after the funding of each loan before purchasing it, it is undisputed that CashCall purchased each and every loan before any payments on the loan had been made. CashCall assumed all economic risks and benefits of the loans immediately upon assignment. CashCall bore the risk of default as well as the regulatory risk. Indeed, CashCall agreed to "fully indemnify [originating bank] for all costs arising or resulting from any and all civil, criminal, or administrative claims or actions, including but not limited to fines, costs, assessments and/or penalties ... [and] all reasonable attorneys fees and legal costs associated with a defense of such claim or action." 128

The court marshalled each of the true lender authorities ${ }^{129}$ and cogently applied a synthesized rule to the above arrangement before concluding, "[b]ased on the totality of the circumstances," that CashCall "had the predominant economic interest in the loans and was the 'true lender' and real party in interest." 130

The defendants in CashCall moved for, and the trial court granted, an order certifying interlocutory appeal to the Ninth Circuit for that

126. See CashCall, Inc. v. Md. Comm'r of Fin. Regulation, 139 A.3d 990, 1005 (Md. 2016) (relying in part on determination that CashCall is the de facto lender in its lending arrangements with banks to conclude that CashCall is not exempt from state regulation of "credit services business[es]").

127. CFPB v. CashCall, Inc., No. CV 15-7522-JFW (RAOx), 2016 WL 4820635, at*5-6 (C.D. Cal. Aug. 31, 2016), appeal denied, No. 17-80006 (9th Cir. Apr. 20, 2017).

128. Id. at $* 6$ (final alteration in original).

129. See id. at *5-6 (citing the removal cases, the Georgia statute, Rehoboth Beach, and Morrisey to outline the contours of the true lender doctrine).

130. $I d$. at $* 6$. 
court to weigh in on the propriety of the true lender test. ${ }^{131}$ But the Ninth Circuit, without elaboration, denied the interlocutory appeal. ${ }^{132}$ Accordingly, the true lender opinion stands, and the case has progressed to the damages phase..$^{133}$

\section{B. Madden Under a True Lender Analysis}

Reliance on the true lender doctrine to determine whether a third party is entitled to preemption of state consumer-protection laws would effectively avoid any of the market turbulence sown by Madden. The true lender doctrine seeks, essentially, to expose sham transactions in which a nonbank entity temporarily occupies the form of a bank to evade state law. Any assignment of loans that does not give rise to suspicions that this arrangement is at play will not implicate the true lender doctrine at all.

In Madden, Bank of America had originated the loans at issuecredit cards - with an uncontroverted desire to play the role of lender in perpetuity and retain any and all risk relating to the loans, including default. There was no agreement or scheme between Bank of America and Midland Funding by which Bank of America would confer preemptive force on the loans and subsequently sell them to Midland. Bank of America, by any formulation of the true lender test, was unequivocally the real party in interest. That certain accounts defaulted, leading to a loss on Bank of America's balance sheet and a sale of the loan obligations to a third-party collector, cannot change the fact that, at the point of origination, Bank of America was functionally-not just formally-the true lender. Indeed, in this context, the bank was forced to absorb the full impact of the economic risk it assumed after the borrowers at issue defaulted on their obligations.

131. Barbara S. Mishkin, Federal District Court Certifies Interlocutory Appeal in CFPB Lawsuit Against CashCall, BALLARD SPAHR LLP (Jan. 19, 2017), https://www. consumerfinancemonitor.com/2017/01/19/federal-district-court-certifies-interlocutory-appeal-incfpb-lawsuit-against-cashcall [https://perma.cc/DNF3-JWFE].

132. See Order Denying Interlocutory Appeal, CFPB v. CashCall, Inc., No. 17-80006 (9th Cir. Apr. 20, 2017), https://www.consumerfinancemonitor.com/wp-content/uploads/sites/14/2017/04/ order.pdf [https://perma.cc/M7HQ-XC8L].

133. See Order Denying Defendants' Motion for a Stay of Proceedings at 2, CFPB v. CashCall, Inc., No. CV 15-7522-JFW (RAOx) (C.D. Cal. July 7, 2017), ECF No. 253 (directing the parties to file a joint report setting forth a trial schedule for the remaining issues in the case). 
Moreover, the true lender test does not at all affect the bedrock contractual precept of valid-when-made. ${ }^{134}$ The cases identifying nonbanks as the true lender do not hold, as the Second Circuit did in Madden, that the loans at issue have become usurious upon assignment to a nonbank entity. Rather, those cases found that the loans at issue were not actually originated by the bank at all, and that the true originator was in reality the nonbank entity. Accordingly, under the true lender doctrine, the subsequent assignee of loans originated by a bona fide lender-that is, a lender that is not originating loans on behalf of a third party as part of a scheme to evade state consumer laws - is equally entitled to those privileges in effect at the time of origination.

\section{Benefits of the True Lender Doctrine}

As mentioned earlier, rent-a-charter participants are likely to seize on factors identified by courts applying the true lender doctrine and subsequently attempt to structure the form of their relationships so as to avoid the appearance of sham transactions. Indeed, Chapman \& Cutler LLP generated client-facing content outlining the emergence of the true lender doctrine and suggesting that in light of the doctrine's judicial success, rent-a-charter parties should consider implementing structures in which "the bank has substantive duties and/or an economic interest in the program or loans." 135

This suggestion, while sparse on details, illustrates that efforts to structure lending partnerships to evade a finding that the nonbank entity is the true lender will necessarily require the chartered bank to play a greater role in the lending. ${ }^{136}$ More specifically, because courts applying the true lender tests will disregard the names parties give to their relationships and will instead seek to determine where the risks genuinely lie, any successful strategy to evade an adverse true lender finding must actually shift some of the lending risk and substantive duties of the lending process to the bank. Accordingly, the virtue of the true lender doctrine is that the more the parties try to avoid the

134. For the contracts law underpinnings of valid-when-made, see supra Part II.

135. Chapman Client Alert: New Federal Court Decision Applies the "True Lender" Doctrine to Internet-Based Payday Lender, CHAPMAN \& CUTLER LLP 2 (Feb. 1, 2016), https:/www.chapman.com/media/publication/601_Chapman_Federal_Court_Decision_Applies_ True_Lender_Doctrine_to_Internet-Based_Lenders_020116.pdf [https://perma.cc/4X5W-75ZX].

136. See id. (stating that the authors were "aware that some internet-based lending programs are considering structural changes" to shift more substantive duties and economic interest to the bank originator). 
appearance of sham transactions, the less the parties actually engage in sham transactions. At some point on the continuum of possible allocations of risk, both credit and legal, between bank and nonbank entity, the bank that is entitled to the protection of the exportation doctrine becomes the lender that enjoys it-perhaps jointly with the nonbank entity.

This development may have two salutary effects, elaborated below, on rent-a-charter activity. First, instead of serving as a mere conduit, the bank, because its balance sheet is now actually exposed to the nonbank's credit decisions, must undertake affirmative efforts to monitor the quality of loans it originates. Second, the more these loans remain on the books of banks, the more they are subject to the bank's regulators, ${ }^{137}$ if only by proxy, and the more likely they are to be in compliance with fundamental principles of bank risk management and consumer protection.

\section{Dodd-Frank's Reliance on Risk Retention and How the True} Lender Doctrine Encourages the Same Realignment of Incentives. Federal regulators, as mandated by Dodd-Frank, ${ }^{138}$ are increasingly employing the concept of risk retention as a regulatory tool to remedy misaligned incentives between originating entities and subsequent owners of debt. ${ }^{139}$ In response to the perception that the absence of credit risk exposure for originators ${ }^{140}$ caused pervasive deterioration of

137. Very generally, nationally-chartered banks have as their primary regulator the OCC, and state-chartered banks are monitored at the federal level by either the Federal Reserve or the FDIC (depending on whether the bank elects to join the Federal Reserve System), and are additionally under the supervisory jurisdiction of relevant state banking authorities. For a more complete description of which banks are monitored by which regulators, see MARK JICKLING \& EDWARD V. MURPHY, CONG. RESEARCH SERV., WHO REGULATES WHOM? AN OVERVIEW OF U.S. FINANCIAL SUPERVISION (2010), https://fas.org/sgp/crs/misc/R40249.pdf [https://perma.cc/ K8XJ-UTGP].

138. See 15 U.S.C. $\$ 780-11(b)(1)-(2)$ (2018) (directing relevant federal banking regulators to propose and promulgate rules that require bank sponsors of asset-backed securities to retain no less than 5 percent of the credit risk of nonexempt securities).

139. See BD. OF GOVERnORS OF THE FED. RESERVE SYS., supra note 86, at 14, 43 (summarizing the incentive alignment problems in securitization processes, and explaining that retention of credit risk "gives securitizers or originators an explicit pecuniary stake in the performance of their assets").

140. See id. at 43-44 (detailing the incentive alignment problems revealed during the financial crisis which were created, in part, because "[o]riginators typically did not retain any interest in individual mortgages sold for securitization"). 
underwriting standards ${ }^{141}$ before the financial crisis, Congress sought to require lenders to retain sufficient risk to prevent the unsound extension of credit. ${ }^{142}$ The gist of these efforts is to incent banks to originate only those loans they would feel comfortable retaining on their balance sheet.

Here, the true lender doctrine accomplishes this same goal, effectively transferring some proportion of risk to the originating bank that, in most cases, would previously have been exposed to zero risk by virtue of the terms of the rent-a-charter agreement. ${ }^{143}$

2. Regulation by Proxy. The Federal Deposit Insurance Corporation (FDIC) and the OCC are each tasked, inter alia, with ensuring the safety and soundness ${ }^{144}$ of the banks they supervise as well as promoting general tenets of fair dealing with customers. ${ }^{145}$ Accordingly, any threat posed to a bank's prudential outlook by virtue of the litigation, compliance, reputational, operational, and credit risks attendant to third-party lending arrangements is squarely within their supervisory purview. In this way, the ability of a bank's primary regulator to ensure both prudential and consumer-protection

141. Underwriting in the lending context refers to the process that banks undertake to ascertain the relative risk of the extension of credit. Factors include individual creditworthiness, loan-to-value ratio, and other indicia of default risk.

142. See generally BD. OF GOVERNORS OF THE FED. RESERVE SYS., supra note 86 (outlining congressional intent in mandating the production of a risk retention study and subsequent rulemaking).

143. See, e.g., CashCall, Inc. v. Morrisey, No. 12-1274, 2014 WL 2404300, at*14 n.19 (W. Va. May 30, 2014) (detailing the agreement between bank and nonbank lender which insulated the bank from all credit and legal risk, and provided for considerable payments to continue originating the nonbank's loans).

144. "Safety and soundness" is bank-regulatory shorthand for a regulator's mandate to prevent the collapse of a bank and its collateral damage to depositors, the taxpayer, and the greater economy. See Making Sense of the Federal Reserve: Safety and Soundness, FED. RES. BANK OF SAINT LOUIS, https://www.stlouisfed.org/in-plain-english/safety-and-soundness [https://perma.cc/2QFG-9MSB] ("The nation's banking system is only as safe and sound as the banks within the system. So the Federal Reserve examines banks regularly to identify and contain bank risks.").

145. See Mission, Vision, and Values, FDIC, https://www.fdic.gov/about/strategic/ strategic/mission.html [https://perma.cc/7EKM-9EAU] ("The Federal Deposit Insurance Corporation (FDIC) is an independent agency created by the Congress to maintain stability and public confidence in the nation's financial system by . . . examining and supervising financial institutions for safety and soundness and consumer protection ...."); About the OCC, OCC, https://www.occ.treas.gov/about/what-we-do/mission/index-about.html [https://perma.cc/BMP3TN7W] ("To ensure that national banks and federal savings associations operate in a safe and sound manner, provide fair access to financial services, treat customers fairly, and comply with applicable laws and regulations."). 
compliance in its supervised banks, through formal and informal enforcement mechanisms, ${ }^{146}$ is very likely to have a beneficial moderating effect on third-party lending accomplished through rent-acharter arrangements structured to avoid a finding that the nonbank is the true lender. Quite intuitively, the longer and more substantive the role of the bank in the rent-a-charter arrangement, the more likely it is that the bank's regulators will effectively detect and deter abusive or unsafe practices and encourage or mandate conformance with fundamental principles of safety and soundness and consumer protection.

The FDIC has long recognized the array of dangers that accompany the intersection of nonbank lending and traditional banking, and has periodically provided guidance to its member institutions on properly managing these risks. At various points since 2005, the FDIC has updated its advice to meet new trends in paydaylending relationships with federally insured banks; ${ }^{147}$ in 2016, the FDIC proposed guidance on how banks looking to partner with third-party lenders might do so more responsibly, by mitigating credit, compliance, and operational risk..$^{148}$ The FDIC's proposed guidance would require that banks "engaging in significant third-party lending activities . . . maintain capital ${ }^{149}$ well-above regulatory minimums," $" 150$ and would increase the frequency of such bank's examinations. ${ }^{151}$

Although the OCC has consistently advocated for an expansive conception of preemption of state consumer-protection laws for national banks ${ }^{152}$ it has also recognized the risks inherent in permitting nonbanks to access the privileges accorded to traditional banks, and has periodically issued guidance to nationally chartered banks that

146. See BARR ET AL., supra note 24, at 841-45 (summarizing the various formal and informal enforcement mechanisms by which federal and state regulators seek to ensure the safety and soundness of banks).

147. FDIC, FIL-14-2005, GUIDELINES FOR PAYDAY LENDING (2015), https://www.fdic.gov/ news/news/financial/2005/fil1405a.html [https://perma.cc/U34A-CVZU].

148. FDIC, FIL-50-2016, EXAMINATION GUIDANCE FOR THIRD-PARTY LENDING (2016), https://www.fdic.gov/news/news/financial/2016/fil16050a.pdf [https://perma.cc/M9AJ-FEPW].

149. In the bank-regulatory context, capital functions both as a metric of a bank's stability and as a tool for regulators to ensure that a bank's loss-absorbing cushion is commensurate with its risk profile so as to prevent the need for taxpayer bailouts. See BARR ET AL., supra note 24, at 259 ("In functional and slightly idealized terms, capital measures the amount of losses that an institution can suffer without impairing its obligations to creditors and other claimants.").

150. FDIC, supra note 148 , at 11 .

151. Id. at 13.

152. For a discussion of the OCC's promulgation of broad preemption determinations for national banks, see supra notes 52-54 and accompanying text. 
elect to enter into third-party lending relationships. ${ }^{153}$ Like the FDIC's recommendations, the OCC's bulletins and advisory letters urge national banks originating loans on behalf of third parties to play an active role in monitoring the quality of the loans and the behavior of the third-party lender. ${ }^{154}$ The OCC additionally promulgated rules providing that, when the OCC determines that it must conduct an investigation into a bank's third-party relationship, that bank must pay the assessment of special examination fees. ${ }^{155}$ The OCC went so far as to put rent-a-charter parties on notice in 2000 by warning that they "should not assume that the benefits of a bank charter, particularly with respect to the application of state and local law, would be available to them." ${ }^{156}$

A bank's primary regulatory supervisor exerts considerable influence over its operations in ways that few regulatory entities can claim vis-à-vis most third-party lenders by providing general guidance about best practices alongside the omnipresent threat of informal and formal enforcement processes. By virtue of this influence, loans originated through third-party relationships in which the bank assumes a substantive role in the lending with a continued economic interest in the loans are likely to be more compliant with fundamental principles of bank risk management and consumer protection.

\section{Benefits over a Statutory Approach}

It may be said that courts are inappropriate actors to eradicate these sham transactions. But unlike a legislative approach, the inherent agility of the true lender doctrine as applied by courts will ensure that the effort retains teeth. Even if meaningful legislation is enacted, free from loopholes that undermine its efficacy, a statutory approach

153. See OCC, OCC Bull. No. 2013-29, Third-PARTy Relationship (2013), https://www.occ.treas.gov/news-issuances/bulletins/2013/bulletin-2013-29.html [https://perma.cc/ VE29-JEGA] (warning of the risks to banks posed by third-party relationships in the absence of adequate ex ante due diligence in conjunction with ongoing monitoring of the third party's behavior); OCC, ADVISORY LETTER 2000-10 ON PAYDAY LENDING (2000) ("Such third-party arrangements significantly increase risks to the bank and the OCC's supervisory concerns.") [hereinafter OCC, ADVISORY LETTER].

154. Id.

155. See 12 C.F.R. $§ 8.6$ (2018) (providing for the assessment of additional supervisory fees against the bank to cover the cost of investigations "if the OCC determines that assessment of the fee is warranted . . because of the high risk or unusual nature of the activities performed" by the third party).

156. OCC, ADVISORY LETTER, supra note 153. 
cannot adequately anticipate innovations in rent-a-charter arrangements.

The saga of the Home Ownership and Equity Protection Act (HOEPA) is instructive here. ${ }^{157}$ The legislation targeted subprimemortgage lending in light of reports of increasingly abusive home lending practices. ${ }^{158}$ It increased disclosure requirements at the point of origination, imposed statutory damages against lenders for violations, and created liability for entities that subsequently purchase subprime mortgages that do not conform to HOEPA's standards. ${ }^{159}$ But the static nature of the statute meant that "lenders could easily evade HOEPA's restrictions by structuring loans to fall just below HOEPA's bright line, high thresholds." 160

Here, however, the dynamic quality of the true lender doctrineand the courts' ability to animate it - is uniquely positioned to avoid the kinds of shortcomings displayed by legislative efforts like HOEPA. A judicial doctrine that is capable of identifying the real incentives of the parties without regard to the obfuscating names or forms they employ is likely to be considerably more effective than targeting legislation which sets forth discrete floors or ceilings which can be easily evaded by nonbank lenders. ${ }^{161}$ That the doctrine relies heavily on a fact-intensive, totality-of-the-circumstances analysis militates strongly in favor of a judicial approach, inherently more capable of adjudicating arrangements on a case-by-case basis. Indeed, the nontheoretical contours of this test have yet to be delineated precisely, owing principally to the small number of cases resolved on the merits. Courts are the most competent institution to mold the shape of the doctrine when parties invariably begin to alter their arrangements to avoid legal risk. To be sure, the arrangement at issue in CashCall

157. Home Ownership and Equity Protection Act, Subtitle B of Title I of the Riegle Community Development and Regulatory Improvement Act of 1994, Pub. L. No. 103-325, 108 Stat. 2190 (1994) (codified as amended in scattered sections of 15 U.S.C.).

158. BARR ET AL., supra note 24, at 593.

159. Id.

160. Id. Additionally, by the time HOEPA was enacted, the mortgage industry had successfully lobbied for the inclusion of a series of carve-outs, the largest of which removed purchase mortgages - that is, "first mortgages"-from its ambit entirely. Id. As even a casual observer of the financial crisis of 2008 would surmise, the statute did not effectively curtail abuse in the subprime mortgage market. See id. (explaining that between 2004 and 2011, the act applied to less than one half of one percent of all nonpurchase mortgages).

161. Congress could, of course, codify the basic principles of the true lender doctrine. But the fact-bound application of such a statute is certain to rest, at some level of review, with the courts where the doctrine already exists. 
presented perhaps the most clear-cut form of a sham transaction: the parties employed a relationship blatantly designed to bypass interestrate limits. If this type of transaction represented the final attempt by rent-a-charter participants to create a sham transaction, Congress could draft a statute to effectively dispose of the phenomenon by proscribing the structure presented in that case. But rent-a-charter parties will invariably tweak their structure ${ }^{162}$ in pursuit of the same end - an end run around state consumer-protection laws - with only minimal reallocation of lending risk. Accordingly, the incremental method of the common law, guided by continual judicial appraisals of the impact on parties of the most recent judicial application of the doctrine, is well positioned to define the metes and bounds of the doctrine.

It is true, of course, that such an approach will involve an element of uncertainty on the part of rent-a-charter participants. But this uncertainty is clearly different in scope and kind from that generated by the Madden decision. The true lender test specifically targets actors entering into bank partnerships with the intent to evade state interest rate limitations and other consumer-protection laws, a group that can be fairly charged with an awareness that their activities are afield of any kind of safe harbor. Moreover, the uncertainty faced by rent-acharter parties is no different from any common law doctrine whose deployment is necessarily a fact-intensive endeavor. Like a finding of unclean hands or lack of good faith, courts can only identify the true lender on the basis of all the facts before them, and parties seeking to structure their behavior accordingly must do so by analogy to adjudicated cases. ${ }^{163}$

Additionally, banking regulation should be fundamentally conceptualized as a tradeoff. As Professor Howell Jackson explains:

The premise ... is that an entity should not be allowed to engage in the business of banking unless the entity complies with the regulatory

162. For a discussion of measures that rent-a-charter parties are presently considering to avoid a finding that the third party is the true lender, see infra Part III.C.2.

163. Some practitioners in the FinTech area have noted that the true lender jurisprudence provides ample guidance for more legitimate nonbank lenders. See, e.g., Chris Bruce, Appeals Court May Tackle 'True Lender' Debate Affecting Fintechs, Online Lenders, BLOOMBERG L.: BANKING (Mar. 30, 2017), https://www.bna.com/appeals-court-may-n57982085931 [https:// perma.cc/48LK-MBQW] (quoting a partner at Goodwin Procter who believes that the test from CashCall "can be helpful because it provides a little bit of a roadmap," adding that "[t]he predominant economic interest test is a higher-bar test for bank partnerships, but one that bank partnerships can satisfy"). 
safeguards designed to restrain the risks associated with depository institutions and also presumably complies with the social obligations and political constraints imposed on the banking industry. ${ }^{164}$

This conception of banking helps to explain the asymmetrical relationship between banks and their regulators, for which there is no analogue in the relationships between other industries and their regulators. Indeed, it is this same justification on which financial regulators base their imposition of a variety of regulatory mechanisms whose precise form is purposely unclear ex ante. For instance, the precise inputs and formula for the Federal Reserve's annual stresstesting processes ${ }^{165}$ remain generally opaque. ${ }^{166}$ This lack of transparency, while bitterly opposed by banks, is defended on grounds that it is necessary to prevent banks from gaming the models so as to appear more financially healthy than they actually are. ${ }^{167}$

As with any other condition on the business of banking, the uncertainty faced by banks who elect to enter into third-party lending relationships as a result of an under-defined true lender doctrine is simply an extension of this logic: an unavoidable restraint on the risks associated with those institutions who have been permitted to engage in the business of banking.

Finally, even if the true lender doctrine was amenable to distillation by statute or rulemaking, any push to achieve this end will invariably run headlong into a federal government that is openly hostile to financial regulation. Clearly, the current administration, Congress, and the CFPB are each motivated and well-positioned either to eliminate consumer-financial regulations or to reduce the

164. Howell E. Jackson, Regulation in a Multisectored Financial Services Industry: An Exploratory Essay, 77 WASH. U. L.Q.319, 368 (1999). A more contemporary example of this view is found throughout the OCC's white paper exploring the grant of a limited charter for marketplace lenders. See OCC, supra note 14, at 1 ("[I]f [the OCC] decide[s] to grant a national charter to a particular fintech company, that institution will be held to the same high standards of safety and soundness, fair access, and fair treatment of customers that all federally chartered institutions must meet.").

165. Stress testing refers to two processes-Comprehensive Capital Analysis and Review, and the Dodd-Frank Act Stress Tests, both of which are accomplished by the Federal Reserve-in which the financial health of the largest bank holding companies is evaluated based on how their balance sheets would fare when subjected to varying degrees of adverse economic conditions. See BARR ET AL., supra note 24, at 308-12 (explaining the impetus, rationale, and operation of stress testing).

166. See id. at 313 (noting criticism of the confidentiality of stress-testing models and assumptions).

167. See id. (explaining that the Federal Reserves' rationale for declining to disclose detailed assumptions and model inputs is to prevent banks from gaming the models). 
enforcement of extant consumer-financial laws. President Donald Trump has advocated for the repeal of Dodd-Frank both as a candidate $^{168}$ and as president, ${ }^{169}$ and his administration reportedly considered "making a high-profile run on the [CFPB]," but decided against that path after polling data revealed an agency "too popular to pick a public fight with.”170

In November of 2017, however, President Trump was finally able to begin remaking the CFPB by appointing Mick Mulvaney-whose avowed beliefs are inimical to the CFPB ${ }^{171}$ - to be the acting director of the agency that had secured the most full-throated judicial endorsement of the true lender doctrine to date. ${ }^{172}$ Since leading the CFPB, Mulvaney has halted rulemaking, imposed a freeze on new enforcement actions, and actively lobbied legislators to pursue congressional invalidation of a CFPB rule governing short-term lending that was promulgated before Mulvaney arrived. ${ }^{173}$

Meanwhile, the only real question in Congress is which version of financial deregulatory reform will garner enough support to become

168. See Emily Flitter \& Steve Holland, Trump Preparing Plan to Dismantle Obama's Wall Street Reform Law, REUTERS (May 17, 2016, 8:14 AM), https://www.reuters.com/article/us-usaelection-trump-banks/trump-preparing-plan-to-dismantle-obamas-wall-street-reform-lawidUSKCN0Y900J [https://perma.cc/9YXC-EMLU] (reporting on then-candidate Trump's plan to repeal Dodd-Frank).

169. See Benjamin Bain \& Jesse Hamilton, Trump Pledges 'Big Number' on Dodd-Frank in Anti-Rule Push, BloOmberg Politics (Jan. 30, 2017), https:/www.bloomberg.com/news/ articles/2017-01-30/trump-pledges-big-number-on-dodd-frank-in-anti-regulatory-push [https:// perma.cc/62J2-XFX3] (quoting President Trump's promise "to do a big number on DoddFrank").

170. Steve Eder, Jessica Silver-Greenberg \& Stacy Cowley, Republicans Want To Sideline This Regulator. But It May Be Too Popular., N.Y. TIMES (Aug. 31, 2017), https://www.nytimes.com/2017/08/31/business/consumer-financial-protection-bureau.html [https://perma.cc/W75S-E4GS].

171. See Renae Merle, The CFPB Now Has Two Acting Directors. And Nobody Knows Which One Should Lead the Federal Agency, WASH. POST (Nov. 24, 2017), https://www. washingtonpost.com/news/business/wp/2017/11/24/the-cfpb-now-has-two-acting-directors-andnobody-knows-which-one-should-lead-the-federal-agency/?utm_term=.1dcfccc520f 4

[https://perma.cc/H32C-JDKH] ("Trump proposed his White House budget director, Mick Mulvaney, as the acting director of the CFPB, which Mulvaney once called a 'joke' and said he wished didn't exist.").

172. For a review of CashCall, Inc., see supra notes 127-35 and accompanying text.

173. See Ian McKendry, Mulvaney's First Days at CFPB: Payday, Personnel and a Prank, AM. BANKER (Dec. 4, 2017, 8:00 PM), https://www.americanbanker.com/news/cfpbs-mulvaney-backscongressional-repeal-of-payday-lending-rule [https://perma.cc/Z8MH-PG9R] (detailing Mulvaney's actions in the initial weeks of his CFPB tenure). 
law: the House's extreme Financial CHOICE Act, ${ }^{174}$ passed by the House in June 2017 along party lines, or a more moderate bipartisan bill making its way through the Senate. ${ }^{175}$ Even if the current CFPB leadership resumed the operation of the bureau consistent with its mission, this Congress has displayed a clear desire to exercise any controls at its disposal to block the proliferation of consumer-financial regulation. ${ }^{176}$ With a president, Congress, and the CFPB intent on achieving a decrease in financial regulation and associated enforcement, any suggestion that a statutory or administrative approach is preferable to the true lender doctrine is not generally tenable.

\section{CONCLUSION}

The modern scope of the exportation doctrine bears little relationship to its historical justification. Moreover, the exigencies of consumer protection and the mitigation of future financial crises militate strongly in favor of the doctrine's curtailment. Nonbank entities, at minimum, should not be allowed the benefit of the doctrine by temporarily occupying banks for the sole purpose of originating loans that are immune from state financial-consumer-protection laws. The experience of the Madden ruling cautions strongly against a blunt, overly broad ruling, while the inefficacy of HOEPA weighs against legislation that may prove unresponsive or watered down upon its enactment. The true lender doctrine's singular focus on substance over form, combined with judicial agility to examine each factual constellation and detect any obfuscating formalities implemented by rent-a-charter parties, is presently the most effective way to sensibly limit the reach of the exportation doctrine. And, to the degree that banks assume more substantive duties in the lending process and retain some measure of risk in seeking to comply with the doctrine, the results

174. Financial CHOICE Act of 2017, H.R. 10, 115th Cong. (as passed by House, June 8, 2017). Transparently hostile to consumer financial protection, the CHOICE Act forbids the CFPB from even maintaining a database of complaints received from consumers, $i d$. $\$ 724$, and completely eliminates the agency's authority to proscribe unfair, deceptive, and abusive acts and practices by depository institutions, id. § 735 .

175. Economic Growth, Regulatory Relief, and Consumer Protection Act, S. 2155, 115th Cong. (as reported by S. Comm. on Banking, Hous. \& Urban Affairs, Dec. 18, 2017).

176. See Joint Resolution Providing for Congressional Disapproval Under Chapter 8 of Title 5, United States Code, of the Rule Submitted by Bureau of Consumer Financial Protection Relating to "Arbitration Agreements," Pub. L. No. 115-74, 131 Stat. 1243 (2017) (invalidating the CFPB's consumer-financial arbitration rule that had been promulgated pursuant to express authorization of Dodd-Frank). 
are broadly consistent with regulatory approaches that have been deployed in the wake of the financial crisis. 